there is an important horizon at least $10 \mathrm{~km}$ long in which diopside occurs, in many places as giant crystals up to $30 \mathrm{~cm}$ long.

In the westernmost part of the belt there is a clear tendency for the strike of the supracrustal rocks to bend around from north-south, through east-west to north-east - south-west. However, movements along the main ENE trending fault, veining by Amîtsoq gneiss and poor exposures obscure this feature to some extent.

Horizons of banded ironstone and of banded quartzites have been very valuable as marker horizons. It is clear that deformation has been concentrated in the quartzites and in the acid metavolcanic unit in contrast to the amphibolites which apparently behaved as more competent rock units. The quartzites are generally internally folded and in one locality three successive phases of deformation can be detected. Important fold closures have been found only in two places in the supracrustal belt and these are marked by significant horizons of banded ironstone and banded quartzite.

\title{
References
}

Allaart, J. H. 1975: Field mapping of the pre- 3760 m.y. old supracrustal rocks of the Isua area, southern West Greenland. Rapp. Grønlands geol. Unders. 75, 53-56.

Bridgwater, D. \& McGregor, V. R. 1974: Field work on the very early Precambrian rocks of the Isua area, southern West Greenland. Rapp. Grønlands geol. Unders. 65, 49-54.

James, P. R. 1975: Deformation of the Isua supracrustal belt, southern West Greenland. Rapp. Grønlands geol. Unders. 75, 56-58.

Keto, K. 1970: Isua, a major iron discovery in Greenland. Kryolitselskabet Øresund A/S, 13 pp.

Moorbath, S., O'Nions, R. K. \& Pankhurst, R. J. 1973: An early Archaean age for the Isua iron-formation. Nature phys. Schi. 245, 138-139.

\section{Mapping of Archaean rocks in the inner Godthåbsfjord region, southern West Greenland}

\section{Brian J. Walton}

An area of about $600 \mathrm{~km}^{2}$ was mapped on 1:50 000 scale in the inner part of the Godthåbsfjord region, during the period June to September 1975 (fig. 25). This area is to the north-east of Godthåb and of the classic area described by McGregor (1973). Terminology of the rock units described here are taken from that paper.

The largest part of the studied area is made up of a continuation of the Qôrqut granite which crosses Kapisigdlit fjord, continues north-eastwards through Kangiussap nunâ and could be seen to occur north-east of the upper part of Godthåbsfjord (Kangersuneq). The granite is mainly emplaced within Nûk gneiss but north of Neriunaq it intrudes Amîtsoq gneiss. Another large outcrop of Amitsoq gneiss occurs in the north-west of the area near 


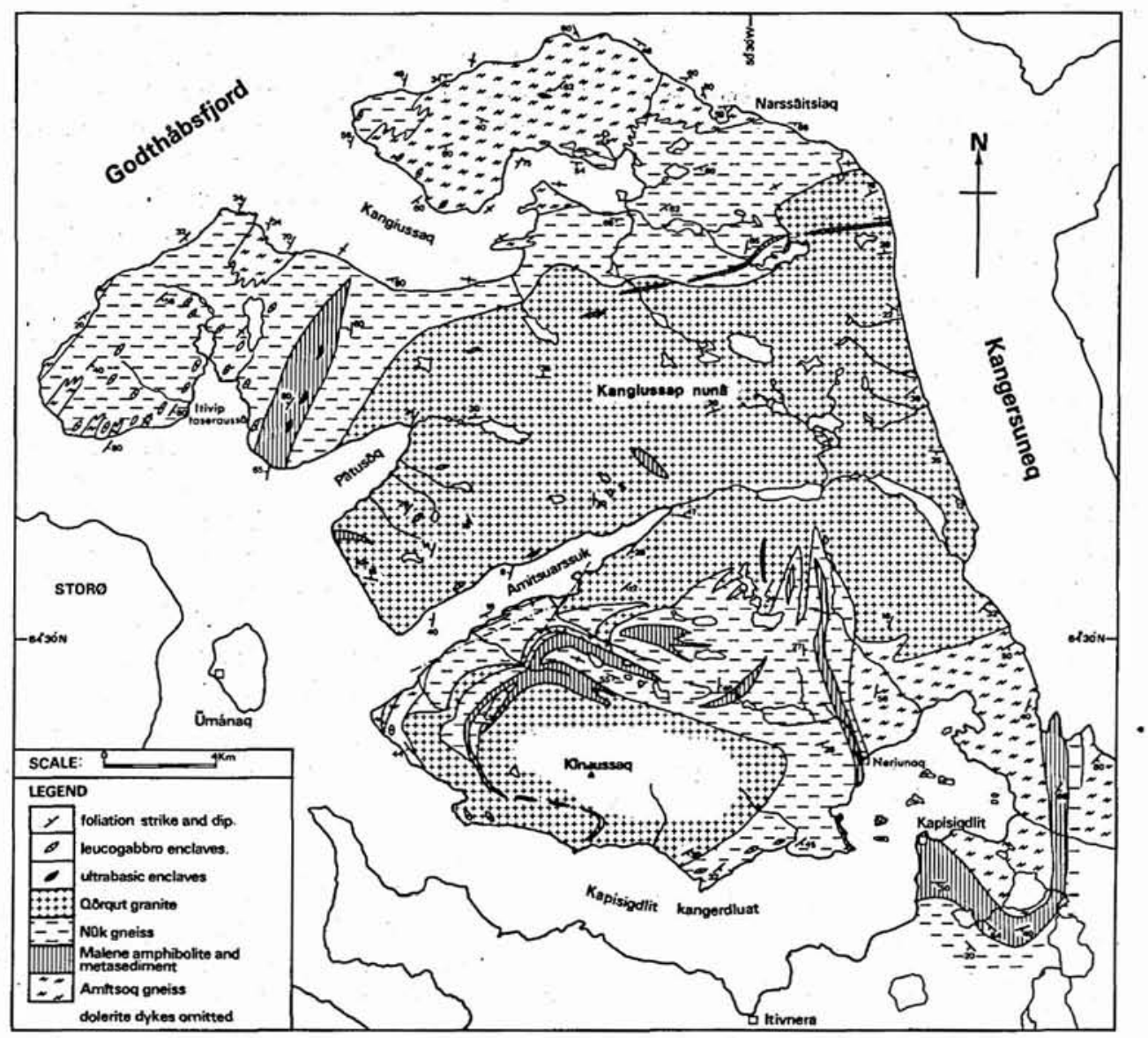

Fig. 25. Geological sketch map of Kangiussap nunâ, Godthåbsfjord region, southern West Greenland.

Kangiussaq. Both the Nûk and Amîtsoq gneisses display mineralogy of the amphibolite facies of metamorphism.

\section{Amîtsoq gneiss}

The Amitsoq gneiss is typical intensely and irregularly folded, although close to the boundary with areas of Nûk gneiss the folding is apparently simpler and the gneiss appears to be more regularly banded. It contains abundant amphibolite inclusions, many of which appear to be derived from Ameralik dykes. These amphibolites occur mainly as concordant lenses of a distinctive massive-textured amphibolite which sometimes contains relic plagioclase phenocrysts. In places these lenses are arranged in what appears to be a relic dyke form, but often they are more evenly distributed through the gneiss. These amphibolites are often quite heavily migmatised by granitic and pegmatitic veins, presumably of Nûk age. 
The Amîtsoq gneisses often contain strips of more banded amphibolite presumably of supracrustal origin. In many places the gneiss is hornblendic and often this appears to have resulted from the intense migmatisation of supracrustal amphibolite. As might be expected this feature is less common in the Nûk gneiss. Ultrabasic lenses are common in the Amîtsoq gneiss, particularly in association with supracrustal amphibolite. In places these lenses are good peridotites or dunites and one example was of a lens with a remarkable relic igneous texture of randomly oriented bladed olivine crystals up to $10 \mathrm{~cm}$ in length with interstitial grey spinel crystals. This texture is similar to those in peridotite lenses associated with presumed Malene supracrustal amphibolites north of Bjørnesund in the Fiskenæsset region (Walton, 1973). However, most of the pre-Amitsoq ultrabasic lenses have reacted strongly with the enclosing granitic gneiss and have become zoned with anthophyllite-actinolite-biotite or hornblende rims and talc-rich cores which are locally good soapstones. Peridotite bodies associated with the Malene amphibolites or Nûk gneisses are generally less zoned. Small hornblendite inclusions $(10-50 \mathrm{~cm})$ are particularly characteristic of the Amîtsoq gneisses and presumably mainly formed from thoroughly metamorphosed and disrupted peridotite.

The Amîtsoq gneiss quite often contains inclusions of leucogabbro which are essentially similar to those found in Nûk gneiss, but tend to be more deformed and recrystallised so that the relic igneous texture is less well preserved. Good examples are found on the north coast of Kangiussaq. It therefore seems likely that a major gabbro-anorthosite body was intruded into the pre-Amîtsoq supracrustals. Only one example of the peculiar iron-rich rocks reported by McGregor \& Bridgwater (1973) from the pre-Amîtsogs was observed and the impression obtained from this area is that there were two essentially similar supracrustal/plutonic cycles at about $3700 \mathrm{~m} . \mathrm{y}$. and $3000 \mathrm{~m} . \mathrm{y}$. ago respectively.

\section{Nûk gneiss}

Nûk gneiss makes up a large part of the area particularly on either side of the Qôrqut granite dome. The gneisses are predominantly creamy-white weathering biotite gneisses of polyphase plutonic origin comprising several generations of granitic-granodioritic sheets and pegmatites deformed to varying extents. In spite of this complexity the foliation very often shows a regular, straight banding in contrast to the intense, irregular minor folding typical of the Amitsoq gneisses. The nature of the boundary zone between the Amîtsoq and Nûk gneisses could be seen at several localities such as on the coast of Kangersuneq, north-east of Kapisigdlit and near Narssaitsiaq, north-east of Kangiussaq. In each case over a distance of about $500 \mathrm{~m}$ a tectonic-plutonic transition occurs such that towards the boundary the Amîtsoq gneiss becomes more regularly banded and concordant with the Nûk gneiss foliation. In the transition zone strips of Amîtsoq gneiss with clearly recognisable relic Ameralik dyke lenses alternate with typical Nûk gneiss.

\section{Amphibolite dykes}

A few examples occur of discordant amphibolite dykes, up to $1 \mathrm{~m}$ thick, which are very little disrupted or migmatised. These cut Amîtsoq gneisses containing strongly disrupted Ameralik dyke lenses and one dyke cuts the transition zone from Amîtsoq to Nûk gneiss, so they 
appear to be essentially of Nûk or late-Nûk age. Other thin, irregular amphibolite dykes cut the Nûk gneisses and leucogabbro inclusions especially near Itivip taseraussâ. These are strongly deformed and so are presumably of rather early Nûk age.

\section{Malene supracrustals}

The Nûk gneisses contain abundant strips of Malene supracrustal amphibolite often associated with metasediment. Near Kapisigdlit these supracrustals are continuous for about $22 \mathrm{~km}$ around a major overfold, and at Kangârssuk are about $1 \mathrm{~km}$ thick, but otherwise they are preserved as smaller, discontinous lenticular strips. In one or two places the amphibolites contain light green lenses which may be relic pillow structures. Metasediments are very well preserved on the coast at Kangârssuk and are mainly biotite-quartz gneisses frequently containing sillimanite. Some very distinctive horizons are rich in anthophyllite, staurolite, cordierite and garnet. Metasediments are also well preserved near Kapisigdlit and as a major raft within the Qôrqut granite north of Amitsuarssuk fjord. Near the latter locality another raft consists of a metaconglomerate with rounded boulders of granite and gneiss up to $50 \mathrm{~cm}$ diameter in a biotite-rich matrix.

Peridotite lenses are particularly common in the Malene supracrustal amphibolite at Kangârssuk and occur as well in the Nûk gneisses. These are mainly brown-weathering rocks rich in olivine together with anthophyllite or hornblende.

\section{Leucogabbro inclusions}

Leucogabbro inclusions are extremely abundant in the Nûk gneisses at Itivip taseraussâ and are also quite common west of Kapisigdlit and locally elsewhere. These rocks show a well-preserved relic igneous texture of subhedral to lenticular calcic plagioclase crystals 1-2 $\mathrm{cm}$ diameter with intersertal hornblende of similar size. As such they are similar to much of the cumulus leucogabbro of the gabbro-anorthosite complex near Fiskenæsset. More continuous thin horizons of fine-grained leucogabbro or hornblende anorthosite occur on Kangârssuk and west of Kapisigdlit. Very few samples of mafic gabbro on the one hand or true anorthosite on the other are found and it seems likely that the gabbroic magma underwent much less differentiation in this region as compared with near Fiskenæsset. The relationships indicate that the leucogabbro was almost certainly intruded into Malene supracrustal basalts before the Nûk granitic activity and associated deformation.

\section{Qồrqut granite}

The Qôrqut granite forms the core of a major antiform trending north-east through Kangiussap nunâ, and also the core of a subsidiary, though still large, antiform trending south-east through Kînaussaq. The granite is predominantly medium-grained, non-porphyritic, usually with biotite as the only mafic mineral, but locally containing hornblende. It contains abundant raft-like inclusions of Malene supracrustal amphibolite, metasediment and Nûk gneiss. Close to its eastern margin on Kangersuneq the rafts are of recognisable Amîtsoq gneiss. The foliation of the inclusions is predominantly gently inclined, concordant 
with the major structure, and a relic 'stratigraphy' is remarkably well preserved. In many places the granite can be seen to have a gently-inclined sheet-like structure and it appears to have been intruded as a series of sills of mainly $1-100 \mathrm{~m}$ thickness. The margin is mainly concordant and transitional in that sheets of granite alternate with gneisses which are mainly of Nûk age. However, south-east of Kangiussaq where the gneiss foliation is mainly vertical and striking east-north-east, the granite is discordant consisting of gently-inclined sheets which thin out northwards into the gneisses. In this area an older Malene amphibolite unit can be traced essentially continuously from the granite through Nûk gneiss and back into granite again. Further away from the granite margin thin gently-inclined sheets of granite are frequently discordant to the foliation of the older rocks.

Parts of the granite show a faint biotite foliation or a more distinct parallel pegmatite banding. This is particularly the case near the margins and is well shown on the coast of Kapisigdlit kangerdluat, south-east of Kînaussaq. Such units could perhaps be interpreted as homogeneous Nûk granitic gneiss, but it is clear from the mapping that they are an integral part of the Qorqut granite mass. This also seems to indicate that the granite started to develop in Nûk time and is essentially the final phase of this plutonic activity, being emplaced towards the end of the major deformation of the region.

\section{Structure}

The structure increases in complexity with the age of the rocks. The Qôrqut granite is emplaced in the major antiforms of a dome and basin interference pattern with north-east and south-east striking upright axial planes. The adjacent and intervening synforms are occupied by Nûk gneisses and Malene supracrustals which show late upright folds superimposed on early recumbent isoclines. The structure of the Amitsoq gneisses is very complex. Near Kapisigdlit they form the core of a major isocline with an axial plane striking north-north-east, dipping east-south-east at about $60^{\circ}$ and with an axis plunging southsouth-east at about $40^{\circ}$.

The Malene supracrustals, leucogabbros and Nûk gneisses have been folded together with the Amitsoq gneisses, but the original relationship between the Malene supracrustals and the Amîtsoq gnéiss remains uncertain.

\section{Dolerite dykes}

Unmetamorphosed dolerite dykes up to $25 \mathrm{~m}$ thick cut the Qôrqut gránite and all older rocks. They trend north-south, east-north-east and east-south-east, i.e. approximately the same directions as near Fiskenæsset. However, the dykes are much less abundant than further south and relative ages are uncertain. It is suggested that they have a relationship to the preceding Nûk plutonic cycle and represent the final phase of basic igneous activity associated with this cycle. The Ameralik dykes probably bear a similar-relationship to the Amitsoq cycle, though they are of course, much more abundant in this region.

\section{References}

McGregor, V. R. 1973: The early Precambrian gneisses of the Godthåb district, West Greenland. Phil. Trans. $R$. Soc. Lond. A, A, 273, 343-358. 
McGregor, V. R. \& Bridgwater, D. 1973: Field mapping in the Precambrian basement in the Godthåbsfjord district, southern West Greenland. Rapp. Gronlands geol. Unders. 55, $29-32$.

Walton, B. J. 1973: The structure and stratigraphy of the anorthosite complex in the area north of Bjørnesund, near Fiskenæsset. Rapp. Grønlands geol. Unders. 51, 60-64.

Department of Chemistry and Geology, Portsmouth College of Technology,

Burnaby Road,

Portsmouth P01 3QL,

U.K.

\title{
Investigation of Precambrian rocks in the Buksefjorden region, southern West Greenland
}

\author{
Kenneth Coe, Paul Compton, John G. Stainforth, \\ Kenneth J. Vines and Peter R. A. Wells
}

1975 was the fourth of a six year mapping project of the Buksefjorden map sheet $63 \mathrm{~V} .1$ Nord. By the end of the season $85 \%$ of the sheet had been completed. Four teams took part: J. G. S. continued mapping north of Buksefjorden and extended his area to Ameralik so as to include important fold closures; K. J. V. continued in the area between Alángordlia and Taserssuatsiait; K. C. extended his area south to Taserssuatsiait and P. C. began mapping south of the central Buksefjorden coast. Base for the operations was Midgård (Kalsbeek, this report).

Localities referred to in the text may be found on the map (fig. 26) and by reference to the Geodetic Institute 1:250 000 maps 64 V. 1 Godthaab and 63 V. 1 Faeringehaven.

Chadwick \& Coe (1976) refer to the occurrence of amphibolite dykes of two generations within the period of development of the younger gneisses. Further observations have been made on these dykes and their distribution is shown in fig. 26. The term Neriunaq (for the earlier) and Qáqatsiaq are proposed for these dyke suites. All other terms are used in the established sense (McGregor, 1973) and with McGregor's original meaning, even though the terminology is in places inadequate. Similarly no changes have been made to the established chronology (Bridgewater et al., 1974: Chadwick \& Coe, 1975) and the uncertainties which have been expressed remain.

One innovation is in the terminology used for structural features. Hitherto the two main periods of deformation affecting the Nûk gneisses (together with older rocks) have been referred to as the isoclinal phase and the asymmetric phase of folding. These are now referred to as $D_{2}$ and $D_{3}$ ( $D_{1}$ relating to earlier structures developed in Amîtsoq gneisses). Limitations imposed by use of the symbols $D_{2}$ and $D_{3}$ are considered to be less important than the advantages which are two fold, viz:

(a) $D_{2}$ and $D_{3}$ can be used for all aspects of the structure associated with a stage of deformation, including fold hinges, axes, axial-surfaces and foliations;

(b) $D_{2}$ and $D_{3}$ carry no implications about fold shape or attitude. 